\title{
ORDINARY PERSON IN MEDIA: \\ PUBLIC INTEREST AND PROFESSIONAL EXPERIENCE
}

\author{
S. G. KORKONOSENKO* ${ }^{*}$ and M. A. BEREZHNAYA \\ St Petersburg State University, Russia \\ s.korkonosenko@spbu.ru*
}

Article submitted in January/2016 and accepted in February/2016

DOI: $10.15628 /$ holos. 2016.4036

\begin{abstract}
This paper is based on the results of the research project "Media Discourses on Material and Ethnic Gaps. A comparative study in St Petersburg and Stockholm" financed by the Foundation for Baltic and East European Studies (Sweden). One of the main sections of the project was focused on ordinary persons' portrayal in comparison with images of so-called celebrities in the regional media. Russian and Swedish scholars used a set of methods such as content analysis of newspapers and TV, expert in-depth interviews, and focus groups (2013,
\end{abstract}

Spring - Summer). In fact, common men appeared rarely in TV excerpts and newspaper articles, especially in Russia. At the same time non-commons were shown in the majority of Russian TV and print media items while Swedish media give the opposite proportions. To explain gaps between Russian and Swedish findings one needs to take into account different social and mental traditions in these countries. The difference has been revealed within expert interviews and focus groups.

KEYWORDS: media discourse, ordinary person, Russia, Sweden, everyday life, similarity to life. 


\section{INTRODUCTION}

In the XXI century it became especially clearly seen that person's self-actualization is tightly linked with the opportunity of self-expression, which, in turn, became a subject of the greatest anxiety. It is necessary to relate self-expression and self-actualization concepts to all members of a society and first of all to ordinary citizens for whom during long history it was more difficult to get access to social "microphone", in comparison with exclusive groups of the population. Thus, the theme of presence of the usual person in media moves to much wider and significant context, than studying of routine practice of mass media.

It is impossible to deny an enormous significance of the new media technologies for raising the role of a person in social and cultural contexts. British theorist R. Silverstone has expressed an essence of the occurred changes in a beautiful intellectual metaphor while named a modern civilization the Mediapolis (2007). Later, this metaphor has been developed in the structure and content of the project realized at the St Petersburg State University (Korkonosenko, 2012). One of the central ideas of the project is that the border between traditional "writer" and "reader" today is erased on technological and mental levels, at least from the viewpoint of equal freedom of communication for each person. Accordingly, former reader's wishes and possibilities for selfrepresentation in media became much higher. Usual people have a right for giving them the floor in media, in different forms including participation in news either as heroes or speakers.

As to Russia, such forms of interaction are incorporated in deep traditions of native culture. The historian of journalism writes: "Experience of the Russian classical literature as well as native cinema and TV documentary teaches us to look closely into realism of the daily life, to observe a life through concealed things - contemporaries' feelings and thoughts..." (Ivanov, 2014, p. 67). In the Soviet journalism the enhanced attention to the usual inhabitant of the country was expressed, in particular, in a wide usage of portrait genres: feature-story, sketch, and interview. Besides, the readers' letters served an effective channel for involving citizens in cooperation with editorial staffs. Authors of reference book on journalism persistently explained to their readers: "As a mediator, a link between big masses of readers and those social institutes which are directly responsible for this or that field of activity, the press provides efficiency of working-people's letters influence on a public practice and thus satisfies interests of both society and its separate members" (Svitich and Zasourskiy, 1988, p. 236). Regardless ideological dogmatism and formalism, a voice of the common person really existed in the Soviet press. It may be supposed, that nowadays people's attitudes and expectations towards persons in media shouldn't be others in general trends. Participants of our research project, both elderly and young ones recollected this practice with evident approval:

\footnotetext{
- Why not to write an essay about the person, from the birth and till today? For instance, he achieved success in his labor. So it was in Komsomolskaya Pravda [Popular newspaper. - Authors] in the Soviet period.

- I miss scientists, technologists. They were before, they were wonderful people. In former times they were being portrayed as usual people but not simple.
}

General objectives of our study consist, first, in revealing today's situation in media concerning simple people's image and voice, and, second, in comparison of media content with public attitudes and expectations in this aspect. A few research questions should be answered in 
this connection: How media professionals, media experts and mass audience representatives understand difference between 'exceptional' and 'ordinary' persons? Which of these categories of people really have their voices on television and in the press? In which thematic contexts are common people portrayed? Whether or not the portrayals are realistic enough to be true reflection of the society's everyday life? We use both Russian and Swedish investigative results for answering the questions.

\section{BACKGROUND AND RESEARCH METHODS}

In broad sense, the theme of the ordinary man is closely connected with the understanding OF EVERYDAY LIFE as a central focus in social science. The concept of everyday life was included in social science discourse due to the persistent efforts of some key thinkers, primarily A. Giddens (Giddens and Sutton, 2013). This conceptual idea has been perceived and elaborated in the field of communication and media, and here experts are concerned about the reliability of the current social reality presentation. In particular, Sh. Moores (2000) detects such problem situations in broadcasting. In turn, the psychological analysis of communications shows that media portrayals of major groups of the population look like distorted social mirrors (Harris, 2004, p. 55). Even more critical are the authors who focus on the role of an ordinary person in the media discourse. By their estimation, "'ordinary people' appear on television more as spectacles of real life and less as authorities on their own lives" (Matheson, 2005, p. 120). Correspondingly, the media construct the illusion of everyday reality: "within play 'realities' are suspended in favour of fantasies, since the rules of play are not those of ordinary everyday life" (Silverstone, 1994, p. 169).

Thus, the study experience of an ordinary person in everyday life media presentation gives rise to problematic situations that require in-depth focused analysis and interpretation. However, special study of this subject did not become a widespread research phenomenon. There are only a few monographic works, and they emphasize: "It becomes clear that while the participation of ordinary people is continually claimed as the benefit to be realized from each development, their actual participation becomes less and less the focus of investigation and research - indeed simply less of an explicit issue - in the relevant academic debates" (Turner, 2010, p. 5). Our study partly fills this gap; in any case, it should add specific materials for understanding the acute problems of social, cultural and professional functioning of contemporary media.

On the basis of preliminary empirical and theoretical background we have found two problem situations, interrelated and confronting between themselves. First situation should be described in a view of the fundamental contradiction: a formal equality in rights vs. an inequality of opportunities of different social strata's representatives. Hypothetically, the actual inequality may be seen in the limited access of simple citizens to the mass media as authors, commentators, and personages of texts.

Second situation has a positive potential energy. We recognize that freedom of the mass information and high technical equipment of the mass media open facilities for a full and all-round reflection of life. In result, such effects are reached which push the media closer to the ideal in their relations to society. This ideal is differently treated and named by researchers. Horst Pöttker in connection with journalism insists on the term publicness: "In the reality of modern societies... publicness has to be sought after and actively constructed... As the profession with the inherent task of producing publicness, its characteristic attitudes and qualities are oriented to its goal of 
transmitting correct and important information to as many people as possible" $(2010,354)$. We prefer to use terms life-similarity, or life like (zhiznepodobie, in Russian). Journalism is similar to life, it is like a life, and its specific nature consists in the similarity to everyday life. Both publicness and similarity to everyday life presuppose participation of the everyday people in the media. Thus, media can overcome social inequalities due to technological power, typological diversity, and adequate comprehension of their own public task and inherent facilities.

To examine the today's situation in media a complex set of empirical methods has been developed and used. It was a result of close collaboration of all project participants but our partners Cecilia von Feilitzen and Peter Petrov from Södertörn University, Sweden played the roles of initiators and final program designers.

The content analysis method was used for studying texts of regional newspapers and TV. In Russia, sampling included: newspapers: a) Sankt-Peterburgskiye vedomosty; b) Vecherniy Peterburg; c) Moy rayon - St Petersburg, Centre; TV-channels): a) Rossia-SPb: "Vesti" \& "Civil Society" programs; b) 100 TV: "Latest News" \& "Reflection of the day" programs; c) NTV-SPb: "Today in St Petersburg" program; d) Fifth Channel: "Open Studio" program. In Sweden, sampling consisted of: newspapers: a) Dagens Nnyheter; b) Mitt i Södermalm; c) Stockholms Fria Tidning; TV-channels (of regional news): a) SVT's ABC-nytt; b) TV4 Nyheterna Stockholm; c) Öppna Kanalen. Periods for study in 2013 consisted of 5 weeks, by date/month: 28/1-3/2 (pilot study), 25/2-3/3, $18-24 / 3,8-14 / 4,13-19 / 5$. All editorial news (without adds, fictions, official documents, etc.) were registered in a sample of mentioned media and periods, but only relevant ones were studied. The researchers used a specially worked out recording coding scheme into a computer system with software data processing. Brief content descriptions and reflexive comments were included to provide a combination of quantitative and qualitative analysis.

The whole numbers of excerpts and their distribution on the Relevance parameter are performed in Table 1. Relevance means that news/articles contain persons of importance for the excerpt and/or that excerpts deal with material or ethnic relations; the third parameter of Relevance is that regional (not global or national) events are performed. It is clearly seen that the most of the figures are close to each other in two countries, more or less. This closeness gives good ground for further comparative analysis.

Table 1. Relevance of the news excerpts to the study parameters

\begin{tabular}{|c|c|c|c|c|c|}
\hline \multirow{2}{*}{ Media } & \multirow{2}{*}{ Country } & \multicolumn{4}{|c|}{ Number of excerpts } \\
\cline { 3 - 6 } & & All & Relevant/\% & Partly relevant/\% & Not relevant/\% \\
\hline \multirow{2}{*}{ TV } & Russia & 615 & $454 / 74$ & $83 / 14$ & $71 / 12$ \\
\cline { 2 - 6 } & Sweden & 313 & $239 / 76$ & $12 / 4$ & $62 / 20$ \\
\hline \multirow{2}{*}{ Newspapers } & Russia & 816 & $608 / 75$ & $50 / 6$ & $158 / 19$ \\
\cline { 2 - 6 } & Sweden & 531 & $393 / 74$ & $42 / 8$ & $96 / 18$ \\
\hline
\end{tabular}

Another empirical method was expert in-depth interview by the standard guide, of $1.5-2$ hours of duration. In Russia, the list of expert includes 9 persons responsible for the regional news in the media studied (newspapers and TV channels), as well as deputies of the regional Legislative Assembly and media researchers.

In parallel 4 focus groups ( 6 persons/group at least) were organized: low/middle educated people, high educated people, ethnic immigrants - permanent residents of St Petersburg, and poor 
native Russians. Dialogues were recorded on tape for later transcription. Such meeting passed rather intensively and with a high interest of interlocutors in studied subject.

\section{FINDINGS \& ANALYSIS}

\subsection{Common and non-common persons in media: statistics of presence}

Questions and technique of empirical research assumed a preliminary definition of criteria on which common people differ from "non-common", or exclusive. The research group did not define specially attributes of the common person, but operated on a principle by contradiction, that is agreed about exclusive persons, namely: experts, politicians, high officials from the city council, significant criminals, celebrities, etc. Thus, for a basis the criterion of a social status was taken, without taking into account personal qualities of characters - moral, intellectual, reputational, and others. Thus, for us the common person is the one who is not included in the "non-common" group.

The content analysis statistics of TV news and newspapers (especially) show that on a frequency of participation common persons visibly lose to non-common persons. In other words, they are absent oftener in comparison with non-commons of different kind (Table 2).

Table 2. Presence of persons in media

\begin{tabular}{|c|c|c|c|c|}
\hline \multirow{2}{*}{ Media } & \multirow{2}{*}{ Country } & $\begin{array}{c}\text { Number of excerpts } \\
\text { (relevant \& partly } \\
\text { relevant) }\end{array}$ & Common persons/\% & Non-common persons/\% \\
\cline { 3 - 5 } & Russia & 537 & $420 / 78$ & $470 / 86$ \\
\cline { 2 - 5 } TV & Sweden & 251 & $215 / 86$ & $83 / 33$ \\
\hline \multirow{2}{*}{ Newspapers } & Russia & 658 & $223 / 34$ & $511 / 68$ \\
\cline { 2 - 5 } & Sweden & 435 & $381 / 88$ & $112 / 26$ \\
\hline
\end{tabular}

Such a characteristic relates mostly to Russia, not to Sweden. We do not think such derivations depend only on different approaches to the definition of non-common persons by both partners. Indeed, in some cases officials of lower range in Russia have been classified as noncommon while similar public servants have been coded as common persons in Sweden. But there are real reasons to do so in Russia as in this country, it is not customary to perceive the majority of officials as public servants and in public opinion they usually possess the authorities' status.

One of experts described in detail this national-cultural characteristic: "In a mass perception the authorities begin from the one who manages regional administration. Obviously they are people who make decisions and can affect something. The chief of a housing office - he is also authorities for the population because it depends on him, whether they will send the worker to repair the water crane or will not send".

Additionally, let's remind that Sweden differs from other Western cultures on the population's attitude to non-common persons. Swedish researcher of the celebrities' characteristic parameters writes about this differentiation: "Celebrities are distanced from the general audience. Maybe less so in Sweden than in the US or the UK" (Rübsamen, 2011, p. 98). No doubts, in comparison with Russia the difference is much bigger, and not only in a case of celebrities but in relation to all officials and other kinds of authorities. 
It is possible to assume also, that the representation of common people is directly connected with priorities in subjects of description. There are such topics which to greater degree stimulate journalists for public dialogue with ordinary citizens; on the contrary: the certain part of topics is though specially aimed at interlocutor from among the officials, outstanding experts, famous artists, etc.

54 topics have been included in the content analysis program; at a stage of data processing there was a necessity to integrate the units by splitting the initial list into some groups. For the basis of grouping the spheres of existence of the social person have been chosen. A few groupsspheres were generated in a result: Business; Consumption; Crime, accidents; Nature; Private; Social groups (communities); Social infrastructure; Socio-political; Spiritual/Cultural; Sports (excluded from the shown statistics); Other issues.

Some spheres give relatively bigger spaces for contacts of media to ordinary citizens, namely Consumption, Crime $\&$ accidents (more often as a victim), Nature, Private, and Social groups. In turn, Business, Social infrastructure, Socio-political, and Spiritual/Cultural spheres belong to more official or elitist sectors of social life.

Table 3. Topic groups' priorities (Russia/Sweden), \%

\begin{tabular}{|c|c|c|}
\hline \multirow{2}{*}{ Topic groups } & \multicolumn{2}{|c|}{ Media } \\
\cline { 2 - 3 } & TV & Newspapers \\
\hline Business & $5 / 7$ & $6 / 8$ \\
\hline Consumption & $12 / 12$ & $5 / 14$ \\
\hline Crime, accidents & $12 / 17$ & $5 / 8$ \\
\hline Nature & $3 / 7$ & $2 / 5$ \\
\hline Private & $7 / 5$ & $8 / 9$ \\
\hline Social groups & $8 / 8$ & $14 / 16$ \\
\hline communities) & $9 / 16$ & $12 / 10$ \\
\hline Social infrastructure & $14 / 10$ & $27 / 10$ \\
\hline Socio-political & $17 / 13$ & $0 / 3$ \\
\hline Spiritual/Cultural & $0 / 2$ & Total number $1127 / 924$ \\
\hline Other issues & Total number $1141 / 521$ & \\
\hline
\end{tabular}

It may be seen that thematic blocks which we have designated as closer to daily life of the ordinary inhabitant, do not prevail quantitatively (Russia/Sweden): 41.8/49.2 on TV and 32.5/46.8 in newspapers. In the Russian media it is visible especially distinctly on a background of the Swedish statistics, in particular in groups Crime, Nature, and Private. At the same time in Petersburg the frequency of texts from the category Spiritual/Cultural (17.0 and 26.8) is rather high; in turn, in this group the solid share belongs to excerpts of historical/educational character and stories about stars of theatre, cinema, arts, etc.

To discover thematic preferences of the Petersburg media in more details, let's turn to statistics on separate themes inside blocks.

A little bit different proportions have been generated on TV and in newspapers though general tendencies also may be seen. The leading group includes Culture, in different dimensions $(6 \% / 15 \%)$, Crime and accidents (11\%/5\%), City planning and infrastructure (4\%/8\%), Reports about or with celebrities (4\%/2\%), Civic activities (4\%/4\%), Legislation (4\%/3\%), Child care and family issues (4\%/1\%), Traffic (3\%/4\%), and Living conditions (4/4). As it seems, only Child care \& family 
issues and Living conditions give an appropriate platform for media dialogue with ordinary people. At the same time, the thematic rearguard is clearly visible. Such themes never appear or occur rarely: Development assistance issues $(0 \% / 0 \%)$, Terrorism (1\%/0\%), Pornography $(0 \% / 0 \%)$, HIV/Aids (0\%/0\%), et al. Also Corruption (popular theme in a political rhetoric) takes rather small place in a media discourse $(3 \% / 1 \%)$ which to a certain extent is an unexpected result. For our aspect of analysis it is especially important that some meaningful representations of the everyday life didn't gain corresponding attention: Homeless persons, Youth, Elderly people, Handicap in the Social groups section; Interior decoration \& home furnishing, Food \& cooking, Travels \& tourism, Consumer issues in the Consumption section, etc.

There are bases for a conclusion that attention to citizens' conditions is not dominant. In St Petersburg the media prefer highlighting those areas of social life where official or institutional events occur. We mean that some kinds of events usually are being described with prevailing participation of officials and/or in a form of report on business discussion in this or that administrative organization. Correspondingly, crimes demand a policemen' presence, city planning is a subject for the city planning committee (or something else in this way), renovation and interpretation of legislation is a sphere of the Legislative Assembly's competence, and similar. It is hardly possible to wait ordinary man presence within these media contexts. Accordingly, very small place for the ordinary people is reserved in the media.

Similar empirical observations can provoke generalizations at a theoretical level. So, the Estonian researcher of a press ascertains, that journalists "have ceased to write about simple people, pages of newspapers are full of stars and criminals. As a matter of fact, today somewhat takes place... the phenomenon of 'asociality of the press'... Asociality means that the press has concentrated on its own interests, values, and life experience" (Titov, 2012, p. 29-30).

\subsection{Common person portraying: trend to positivity}

Nevertheless it is impossible to deny, that simple people appear on TV and on newspapers' pages. Table 4 includes various combinations of positive, neutral and negative characteristics of portrayed persons in relevant excerpts.

Table 4. Characteristics of persons, \% to the total number characteristics

\begin{tabular}{|c|c|c|c|c|c|c|c|c|c|}
\hline \multirow[b]{3}{*}{ Media } & \multirow[b]{3}{*}{ Country } & \multicolumn{8}{|c|}{ Portrayed persons } \\
\hline & & \multicolumn{4}{|c|}{ Common persons } & \multicolumn{4}{|c|}{ Non-common persons } \\
\hline & & 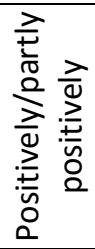 & 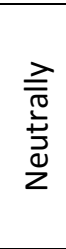 & 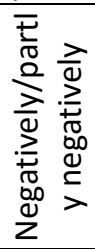 & 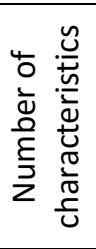 & 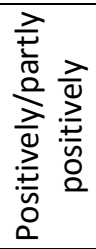 & $\begin{array}{l}\stackrel{\gtrsim}{\overline{0}} \\
\stackrel{2}{ \pm} \\
\frac{0}{2}\end{array}$ & 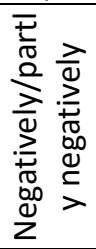 & 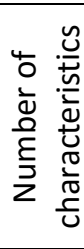 \\
\hline \multirow{2}{*}{ TV } & Russia & 44 & 55 & 10 & 639 & 50 & 38 & 13 & 552 \\
\hline & Sweden & 42 & 39 & 20 & 274 & 45 & 30 & 27 & 88 \\
\hline \multirow{2}{*}{ Newspapers } & Russia & 73 & 21 & 11 & 237 & 74 & 16 & 18 & 537 \\
\hline & Sweden & 44 & 40 & 18 & 527 & 47 & 29 & 29 & 119 \\
\hline
\end{tabular}

Indeed, there are few cases of critical (negative) interpretation of common people in Russian media, both on TV and in the print press $(10 \%$ and $11 \%)$ in comparison with positive and neutral ones. Next conclusion relates to Swedish media where we see more balanced proportions, 
including rather high level of criticism (20\% and $18 \%$ ). The non-common sections also look differently. Generally, Russian media tend to characterizing personages of this kind (mostly in positive way) while Swedish reporters oftener prefer to avoid visible estimation (compare 552/88 characteristics on TV and 537/119 in the print media). In Russia, various non-common figures play highly active roles in public discourse as well as in media content; accordingly, their individualities attract intensive attention.

The positive image of the concrete ordinary town dweller appears, when he acts in a role of a victim (for example, in the conflict with officials and household service), and journalists act in his protection. It is a typical situation for the coverage of conflicts in the sphere of public service of apartment houses. So, in Vecherniy Peterburg which regularly describes such situations, the share of positive characteristics is especially great (27\% in contrast with $3 \%$ in Sankt-Peterburgskiye vedomosty where the given problem is being reflected "without people"). For TV, usual man inclusion is frequently a required professional task. Television news quite often use the social foreshortening method i.e., reflection of a situation from the "simple" person's side: anniversary of the city by the townspeople, instead of authorities, a transport problem by the passenger, instead of the transport committee, building process by the family waiting for own private apartments, etc. The social foreshortening means interest to the man, his life, safety, health, and, hence, provides the information which the person can use for decision-making and which helps him not to make a mistake or to make a correct choice or even to survive. For doing so, an effective creative method there is on TV, namely a personification of news or a problem - a reflection of events through a concrete human story

See some typical examples below. Ten city dwellers have called the newspaper with complaints of the bad public service. Citizens are compelled to pay on the raised tariffs for municipal services, but quality of services does not become higher. The newspaper publishes anti "hit parade" of the housing-and-municipal organizations. It places texts of calls to "a hot line" as well as information about the responsible organizations (Vecherniy Peterburg. March 3). Criminal events also become more colorful in media due to stories with simple people. In the television piece the swindlers offer water filters to pensioners for greater money; they recommend themselves as representatives of the state support program. Journalists expose swindlers and warn inhabitants of danger (Latest News. 9 Apr.). The role of the reporter as an influential person, who is able to help people to obtain justice, is typical for the program Latest news (100 TV). The female pensioner has been sent to psychiatric hospital after her neighbors' complaint because she stated that in her porch someone smoked drugs. The reporter entered the clinic and made video interview by secret camera. Journalists try to protect the woman, and subsequently they gain success (Latest News. 28 Febr.).

One can see that media not only inform on citizens' critical life situations, but also support them, morally on the minimal level and organizationally on the highest one. Undoubtedly, such actions raise a trust of the population in the mass media and to some extent promote strengthening of civil communications in the city community. Finally, it is possible to speak about keeping of social optimism in the people which helps to overcome the difficulties in current living.

At the same time in the display of the simple person in problem circumstances there are stereotypic decisions which are visible both in subjects and in forms of broadcasting. For example, the image of the elderly person habitually is being formed through a prism of a complex of social problems: low pensions, no needed medicines, loneliness, domestic violence, deficiency of social 
service. Videos of "an unfortunate old age" are traditionally used as illustrations to conversation on elderly people' living. Contrarily, themes of employment of old persons, their inclusiveness in society, social rehabilitation, quality of a life which assumes not only financial, but also other components (for example, information, cultural, recreational) are extremely seldom considered. One of experts told about this during in-depth interview: "It is somehow strange to write that some grandmother lives well. All elderly people live badly. The mass media create certain stereotypes".

The state TV programs intended for the aid to vulnerable social groups give appropriate occasions for showing positive changes. Few stories about the social project in Leningrad Region which is aimed at searching home for an elderly person were published. The social working woman looked after the old lady in hospital and then has taken the lady home. Then, journalists show a home for the elderly where inhabitants feel quite comfortable, some of them even marry. Camera shows the dancing woman with a pair of crutches, the married couple describing impressions on their life, the elderly man with a medal in a corridor; all of them are components of the "message" about care which should be given to old men (TV Vesti. 18 March).

For many years the disabled people problems has been a closed theme on Russian TV. People accepted the idea of the accessible environment, co-education of healthy children and kids with the limited opportunities rather reluctantly. However for the last two decades the image of the disabled man on TV has undergone essential changes. In current years the disabled people clearly show themselves as the independent socialized group which do not requires a pity but demands the certain conditions for realization of opportunities. Something of this style may be seen in a report from the Gatchina museum where the excursion program for visually impaired children was created. Small models were built for children that they could visit a palace to the touch. The reporting video, fragments of excursion, interview to the small visitor of the museum everything makes impression of sincere attitude to purblind children (TV Vesti. 26 Febr.).

In opinion of one of experts, in the coverage of a daily life there are few positive news, and especially in connection with simple people: "We need something that would inspire people for life. Small people usually are not so interesting to us. But even there it is possible to find something. I very often come to any families and I listen to them: they do not make exploits, they simply live, simply normally think. And I very much would like to show this".

On similar trajectory answers of focus groups' participants run, when they estimate quality of publication of the positive facts from a daily life:

- I do not have a hero, with whom I associate myself; I mean that simple people have a positive potentiality, but we do not know this, because such a press does not reach us.

- If we have a positive side of a life, it is reported in such context, that officials have presented something to people. Not in that sense that the citizen himself can find the solution and protect his rights.

The idea of responsibility for personal destiny and surrounding life is reflected in the stories about Petersburgers who may be told about "The right man in the right place". For example, in media there are portraits of the persons who are fond of their profession and faithfully serve it (it was a canon genre for the Soviet journalism where the central hero was so-called the man of work). The young man has chosen the turner occupation. Gradually he has started to master machine 
tools with numerical program management. Last year the governor of the city has handed over the diploma "The Best Young Worker" to him. The hero advises boys to master specialties which are accessible to the strong men. Such a choice guarantees them an interesting life and well-being (Sankt-Peterburgskiye vedomosty. 14 May).

In the gallery of simple people's images there are also portraits of such citizens whose singular destiny and bright personal individuality attract high interest of the audience. Vecherniy Peterburg which declares its closeness to citizens regularly publishes such bright pieces. One day it reports that in the age of 105 the oldest female fan of the "Zenith" football club has died. 15 years ago the girlfriend (of the same age) has made her a football fan, and since that moment she had never missed a match of "Zenith" (25 Febr.). In another case the newspaper INTRODUCES

THE amateur artist who produces wooden toys for children, cheerful and practical. This craft actively develops in the world, but in Russia such traditions are almost lost. Creative energy, skillfulness and unselfishness make the hero of the article an attractive person (1 March).

There are no doubts in social and humanistic value of such stories. The context of media (and the context of all public communications in community at the same time) is being filled in with that variety of persons and destinies without which it is impossible to talk about the lifesimilarity of journalism. However, there is a question on motives the pressmen are guided by, as their motivations are not pure altruistic, of course, but can be rather pragmatic and based on commercial interests of the media. Such a statement of a question does not mean mistrust to editorial staffs in a role of adherents of the public blessing, but it opens an opportunity to avoid idealization of their practice.

The bright features of the hero's individuality and behavior can be such a motive, as we could see in some examples above. This idea is present in the statements of the project experts: "When I was responsible for the 'Destiny of the person' section in the newspaper, every week I was to bring an article about a simple person. In the newspaper there may be an article about the yard cleaner if he became the witness of a crime, or if he made cleanup of the Red Square while some presidents were walking there, or if he has won one million in a lottery".

Other project experts (TV reporters) speak about another pragmatic basis in choosing heroes: "Struggling for an audience, the mass media aspire to work as much as possible for the simple man. Newspapers still publish letters, comments, and responses, take any story of unfortunate old woman"; "If you wish to be ostensibly truthful, you should have simple people and should have people from the authorities who work for the common people. To make advances to the population, simple people should appear".

It is hardly necessary to understand the told as professional cynicism; more likely, here a constant necessity of "hunting" for viewers is expressed ("to make advances to the population"), and images of simple people are considered as tools for solution of the certain business problems. At the same time such egoistical (pragmatic) professional ideology can become really a basis of the media company's strategy if other motives of dialogue with ordinary citizens (such as a public duty, sincere interest to the person, and the like) are excluded. Experts pay attention to typical usage of simple people in political or other corporate interests: "Unfortunately, even when someone speaks on behalf of simple people, their voices are used for political purposes i.e., there is no interest to what they really think. The official has come to people, and people tell how they love the authorities, how they are grateful. All of this is falsity and fakes". 
For the population such an imitation is not a secret. In exchange on accessibility of TV for the simple person's opinion participants of focus groups precisely diagnosed inclination of the media to "falsity and fakes":

- It is necessary to make a distinction, whether people receive an opportunity to inform about their position, or they are used as inclusions between the pictures. You tell something, and they cut you out and leave what is necessary for the journalist: "It is fine" - "Here the inhabitant thinks something" - "Now we are coming back to studio and the head of the district is with us ..."

- There is such known expression "Potemkin villages" [Russian idiom which means: "Fakery, a deceptive front that conceals the miserable state of affairs behind the external splendor". - Authors]. On TV in studio ostensibly any audience sits. We make Potemkin village and invite whom? Simple people in the form of crowd scene whom the movie company pays.

Thus, the serious practical problem is found out; it has tight links with the organization of work of the mass media and with the character of demands and claims from the public. On the one hand, both researchers, and functionaries of the media industry, and the public realize the necessity and value of the simple people displaying. On the other hand, occurrence of these people in news is determined by some role characteristics, which are specific for the media production. Media, according to their nature, are not inclined to reproduce a stream of life as one-colored and unremarkable everyday lives; they are aimed at points of growth, bright spots, and objects of curiosity of public. Besides, media are dependent in a choice of the objects for reporting - under pressure of whether external influences, own commercial and corporate interests or a set of different factors, how it usually happens. Accordingly, the figure of the man in media receives the certain functional role: it becomes "point of growth" and "bright spot" mentioned above, a structural element of a telecast or the newspaper article, the supernumerary in political or administrative performance, etc. But in any case, the choice of a role belongs to the editorial staffs, and they are responsible for this choice.

Current global practice gives expressive examples of how particular media and professional community harmoniously combine the social responsibility, humanistic pathos and aspiration to keep the audience.

We'll refer to the program of the American TV: "Heroes CNN - the Simple people changing the world" which is on air for several years. Journalists search for the heroes, but they are prompted also by viewers for whom the special page with the questionnaire for a nomination is opened. Hundreds such "daily" heroes became characters of the stories-acquaintances. Among those who were included in The 2013 Top 10 CNN the most noticeable people are, - enthusiasts, civil activists who create good things. Let's recall the war veteran with prosthetic legs: he helps similar disabled people to move; the owner of small garden: she has grown more than 26000 pounds of fruits and vegetables and distributed them among low-income Americans; the black old lady: she bought a bus with computers and brought technology to the poor children (2013 Heroes, 2013).

It is possible to find something similar in Russia, though in other genre. For example, the National Association of TV and Radio Broadcasters of Russia since 2007 has been holding a festival of socially important TV programs and films "The Hero of Our Time". In the announcement of the 
first festival it was told: "The 'The Hero of Our Time' festival is devoted to one of the 'eternal' questions of the Russian society, the Russian literature, modern cinema and TV... Quality of the labor, public value of labor, recognition - whether these vectors are defining ones in the life of the society? How these processes are presented in television programs and films, how do the authors see the heroes of our time who are ... interesting by characters, civil position, attitude to those numerous changes which are typical for dynamically developing Russia in XXI century" (Pervyi, 2007).

\section{PUBLIC \& THEORETICAL DISCUSSIONS}

The next stage of the research is devoted to subjective perception of the studied questions. We would be interested in interpretations by the focus groups participants and experts of the project. Their impressions should be defined as subjective because all the participants express their own opinions and discussion was not allowed by the scenario.

But there are also reasons of lexical and semantic nature connected with the vague terminology relating to the object of study. Both in Russian and English languages there are big groups of synonyms and quasi-synonyms of the word "common" in application to man: mediocrity, plain, normal, average man, common, ordinary, simple, middling, etc. This semantic riddle has made our interlocutors to guess impromptu, and often it was a difficult task for them.

According to specialists, there is not only linguistic sense in th is definition but also deep social implication and derivative ethical subtleties. Russian office of Radio Freedom received a letter from the listener who was offended at the word "common people" they had used in a program. In reply, they conducted interview with a linguist who explained the meaning of the notion. An adjective "common" has been developing during history: first, it meant "ordinary" and also "plain", "modest"; secondly, a special social meaning became apparent: "common" is the lowest class in the state. Later the expression "common Soviet man" sounded honorably and meant affiliation to all the great Soviet people. Nowadays, in the times of social uncertainty in Russia "common person" sounds as blame. The interview anchor came to the conclusion: a lacuna has appeared in the language and it has become impossible to understand how to define those whom we formerly called "common people" or "ordinary people" (Pal'veleva, 2011).

Adequate meaning of the expression "common person" has become an actual topic in the mass media. In particular, the intention appeared to give the name some humiliation senses. There is a certain professional ideology which interprets an ordinary citizen as persona non grata. It is hardly possible to mask the absence of interest to the bulk of the own city, country, and world inhabitants with the references to lexical incidents.

Deep roots of such an ideology should be found in a wide social and intellectual context which became typical not only for Russia but for other post-communist societies. For example, Czech scholars analyzing "the slackening of the study of media audiences (or ordinary people and their cultures in general)" in this region write: "The study of media audiences was not assigned an especially prominent place in Central and East European (CEE) academia after 'the big bang' in 1989 ... This state of affairs ... is in fact a repercussion of larger socio-political logics which established themselves as unquestioned mainstream discourses underlying the period of post-socialist transformation ... Very rarely academics paid attention to the people that inhabited the structures ..." (Reifová and Pavlíčková, 2013, p. 131, 130). 
From all the above it becomes clear that focus groups participants have to react not so much on the strict meaning of the notion "common person" as on the attitude to this phenomenon which is created in social and media environment. There was a direct question in the focus groups and expert interview guides: "Who are common (non-common) people?" Here are some reactions of focus groups participants.

Higher education:

- There are no such people.

Secondary education:

- Plain country folks.

- There is some image of average statistical individual, social one, and not more.

- Everything depends upon age, interests, relations, all the routine activities, social status.

Poor people:

- Rather strange division. Person, who gets education, works for the benefit of the state - all the people should be of that kind.

Migrants:

- Common person loves his country, cares about the problems, and has his own opinion.

It is not so difficult to see that there is a situation of uncertainty. Interlocutors from different social groups do not propose exact criteria and tend to enwomb themselves in rather general wording. At the same time self-defense intention is more or less evident: participants seem to be afraid to be included in the list of pariah and minor characters at the social stage. This status is characterized with the words "mediocre person" or "philistine". The portrait of such a faceless member of society was proposed by one of the interlocutors (secondary education):

- This is a person whose mode of life is always the same and with nothing extraordinary. It is an average man who works, then comes back home, goes to bed, gets up, has a breakfast, then goes to work ...

Second intention is transferring an accent from a social status of a person (objective characteristic) to his personal features - moral, intellectual, reputational, and others. This way of argumentation is proposed especially urgently and sequentially. Interlocutors are striving to persuade those around them (and probably themselves) that a person being quite common by social position may have such positive features which remove his mediocrity mark. This is also a variant of self-defense:

- Do you consider Roman Abramovitch [Russian millionaire. - Authors] a common person? He has a football club, yachts, and cars. Does he know more than other people? Would it be anything to talk about with him? 
Poor speakers most strongly insist on the distinction of people by their personal endowments:

- If to divide on common and uncommon persons, than only according to their inner characters. Whether he is gifted or not, or maybe he is a genius.

The third intention reveals in appeal to media as to a factor which determines status of a person in public opinion.

- In the mass media context we can define three categories: reputation, money and uniqueness. There are many talentless people, nevertheless newspapers write about them. If he has money, he is a non-common person.

- They are not public opinion leaders, those whom journalists call to ask their attitude because they are well known.

For a comparison, we present experts' view on common people: "Ordinary, common people - they do not high up in the civil service, they do not represent big business or show business"; "Ordinary people - they have no expert's positions in some narrow sphere; they are not nuclear physicist or neurosurgeon"; "First, he does not work in a government body. Second, a common person gets the salary not larger than average in the region".

As we see in comparison with the focus groups discourse, experts draw more crisp outlines of common person figure and they take into account social status or, at least, occupational differences. Probably, due to their professional experience they are more ready to evaluate and classify complicated social phenomena.

There may be an impression that the public has no any certain ideas whether the class of common people exists in reality, who belongs to this class and that the notion of common person itself is falling into disuse. But this is a false and thoughtless impression. Though almost nobody gives strict definitions, speakers (in all the focus groups) use the notion "common person" while talking about the problems of everyday life and its media coverage:

- [In provincial papers they publish] feature stories about common people, for example, about a woman worker from some village.

- Those media which I read do not use the image of common person.

Authors of these and similar statements mention in this or that way such features of common people as social position and publicity level. In other words, division parameters exist for them though not expressed in a verbal form. Thus there is a reasonable basis for questions about how focus groups participants evaluate image of common people in Russian media.

Attempts to reveal the reflection on this matter in straight and univocal way are doomed to fall. First, this analytical question is too hard for inexperienced respondents; secondly, the answer is "crumbling" into the large number of remarks devoted to other topics, especially considering a spontaneous collective speech communication. For example, it is partly included in opinions on information surplus - about whom and what media speak too much:

- Officials, they have full access, they dictate. 
- Media do nothing besides showing the same faces. I mean political groups who use it just as PR to win the votes of electorate.

- Show business representatives are too much.

These remarks are taken from the records of different focus groups but opinion vectors coincide: exclusive figures are presented too much in the media, but not common citizens; such a disproportion does not meet support in the audience. At the same time participants pay attention to the lack of information about ordinary people who don't enjoy exceptional status or media popularity:

- I'd like reportages about groups which solve social problems. Programs about social activity are needed.

- We do not hear the voices of those communities who are discriminated by authority and society, for example, migrants, homosexuals, disabled, HIV-positive people.

- I am interested in creative persons, in those who bring goodness in our life and are able to unite people.

The last remark belongs to a participant from the poor people group and it seems to be symptomatic. Paradoxically, the people with low income and secondary education claim that they are not interested in the common people portraits if they have no exceptional features or do not do something unusual:

- A girl fall in Neva River and a fellow swam to save her. He saved the girl but fall severely ill and died. This fellow can be frankly called a hero in our society.

- Formerly there were newspaper publications like this. I have many old newspapers, of 70s, 60s. My grandfather read them. There are no such stories now.

- It is interesting to read about common people, if there is something to write about them; if there is shocking news their life events are interesting for me.

- The main thing is an interesting story. What kind [of journalist] he is himself, what is his individuality.

The order to journalists is formulated in these statements; this is the order for a certain method of work while creating images of contemporaries: audience wants to see exceptional personalities in media, while social status of the hero fades into the background. In other words, for people it is not enough to watch the portraits of persons who are similar to them (social reason); they want media personages who make everyday life better, more beautiful, generous (aesthetical and psychological reason).

Experts' opinions on this matter are of special interest. Some of them directly discuss the aspect of the psychological search, which demands from author to work hard: "Recently they showed the plumber of African nationality in Saint Petersburg. People admired him as he works artistically, with jokes, does not take extra money. But if a person just works as usually, why should I watch him?"; "We have the professional competition 'Gold Pen'. I am a member of jury in the 
nomination 'Human story'. We try to find out, do we write human stories or not. They have disappeared somewhere because there are no space for them, and no time".

Creative search has contradictions with haste, laziness and apparently a lack of skill. Stereotyping of professional methods is seen in a choice of heroes and in the ways of representation, and it leads to the loss of deep understanding of the reality. Instead, a plenty of celebrities inhabit in media, namely routine set of personages without any high social significance who are shown superficially, in a sensational manner. Media celebrities' phenomenon as socially insignificant one is precisely described by a Sweden researcher: "... You do not need to know or be able to do so much to become a celebrity today. When the focus shifts from what people actually do to what they are and what we can expect them to do ... careers necessarily become swifter... Celebrities come and go with astonishing rapidity in the media industry's constant and relentless quest for new talent" (Rübsamen, 2011, p. 100).

Actually, it is a problem of the idols of the crowd quality. It seems that famous writers as mentors, outstanding thinkers, and film protagonists now are things of the past. Celebrities and bloggers are modern idols and prophets. The outstanding Russian popular writer of science Sergey Kapitsa (the Nobel Winner's son) declared in this connection: "Now it is very difficult to find intellectual leaders in general. Probably, because minds are necessary to nobody - feelings are necessary" (Slaves, 2009).

\section{CONCLUSION}

The carried out analyses of media discourse on common and non-common people gives a contradictory picture in result. On the base of various data we can make general conclusion that media are able not only fix life around, but become the environment where active social interaction of social strata takes place. The condition for this is reflection of the reality in coordinates which are habitual to the majority of the citizens in their everyday life. Meanwhile a transparent wall of exclusive facts, needs and relations (show-windows that fence off journalists and their personages from other citizens) brings the opposite effect. Such a binary opposition does not coincide in any way with myths about the neutrality and objectivity of journalistic community which makes a conscious choice of strategy and forms of professional behavior.

This conclusion directly regards to Russian media. In $90^{\text {th }}$ the Finnish researchers marked its distinctions with journalism of the Soviet period: "Russian journalism has lost much of its previous power and status... Before journalism was highly politicized organ of ideology, but it could also serve as a voice of people within certain limits" (Nordenstreng and Pietiläinen, 1999, p. 155156). Some years later Kaarle Nordenstreng has said again: “... the Russian media system is unique in its historical development. On the other hand, its contemporary character is no longer so special but rather a more or less typical case for highlighting universal problems" (2010, p. 186). The "typical case" means that our conclusions may have international importance, not only national one.

Empirical examination shows that focus groups participants' and experts' opinions coincide (or are close) in many problem points relative to reflection of the contemporaries in the media. Media content and its estimations from different sides demonstrate that the preference 
is given to the topics, facts and images which are far from the everyday life of the majority of people. Thus, along with objective social and material differences, media disproportions appear. Representatives of public (particularly, focus groups participants) do not support such a strategy and aren't satisfied with it. From their evaluation and corresponding content analysis data, the conclusion may be done about the risk to lose substantial matters in media, namely reflection of everyday life and, as a result, similarity to life as an essential characteristic of journalism.

\section{REFERENCES}

1. 2013 Heroes (n.d.). In: CNN Heroes. Retrieved from: http://edition.cnn.com/SPECIALS/ cnn.heroes/2013.heroes/index.html

2. GIDDENS, A. and SUTTON, P. W. (2013). Sociology. 7th ed. Cambridge: Polity.

3. HARRIS, R. J. (2004). A Cognitive psychology of mass communication. 4th ed. Mahwah (New Jersey), London. Lawrence Erlbaum Associates, Inc., Publishers.

4. IVANOV, A. I. (2014). "Byt ili bytie? Neritoricheskie voprosy regional'noi zhurnalistike" (Spiritual vs. material life? Not rhetorical questions to regional journalism). In I. N. Blokhin and S. G. Korkonosenko (Eds.), Zhurnalistika XXI veka: K pravde zhizni (Journalism of the XXI century: Towards the truth of life). St Petersburg: St Petersburg State University; School of Journalism and Mass Communications, pp. 61-68 (in Russian).

5. KORKONOSENKO, S. (Ed.) (2012). Sovremennyi rossiiskii mediapolis (Modern Russian Mediapolis). St Petersburg: Faculty of Philology, St Petersburg State University (in Russian) (in Russian).

6. MATHESON, D. (2005). Media Discourses: Analysing Media Texts. Maidenhead: Open University Press.

7. MOORES, SH. (2000). Media and Everyday Life in Modern Society. Edinburgh: Edinburgh University Press.

8. NORDENSTRENG, K. and PIETILÄINEN, Ju. (1999). Normative theories of the media: Lessons from Russia. In: Ya. N. Zassoursky \& E. Vartanova (Eds.), Media, communications and the open society. Moscow: Faculty of Journalism/Publisher IKAR, p. 146-159.

9. NORDENSTRENG, K. (2010). The Russian media system: Something special? In: E. Vartanova (Ed.), Content, channels and audiences in the new millennium: Interaction and interrelations. Moscow: Faculty of Journalism, Lomonosov Moscow State University, p. 183-186.

10. PAL'VELEVA, L. (2011). Prostoi chelovek (Simple person). Radio «Svoboda», 24 April. Retrieved from: http://www.svoboda.org/articleprintview/9503411.html (in Russian).

11. PERVYI festival' "Geroi nashego vremeni" (First festival "Hero of our time") (2007). Retrieved from: http://www.nat.ru/?an=heroes_2007 (in Russian).

12. PÖTTKER, H. (2010). What kind of European Council? Publicness as the underlying principle in journalistic self-regulation for all of Europe. In: H. Pöttker and Ch. Schwarzenegger (Eds.), Europäische Öffentlichkeit und journalistische Verantwortung (European community and journalistic responsibility). Köln: Halem, p. 351-364.

13. RABI Robsky, obkolotie Koelio (Slaves of Robski are infected by Coelho) (2009). Argumenti $i$ Facti, 9 September. Retrieved from: http://www.aif.ru/society/article/29249 (in Russian). 
14. REIFOVÁ, I. and PAVLÍČKOVÁ, T. (2013). Invisible audiences: Structure and agency in postsocialist media studies. Mediální studia, n. II, p. 130-136.

15. RÜBSAMEN, M. (2011). Approaching celebrity - Sketching an analytical framework. In: I. T. Trivundža, N. Carpentier, H. Nieminen, et al. (Eds.), Critical perspectives on the European mediasphere. The intellectual work of the 2011 ECREA European media and communication doctoral summer school. Ljubljana: Faculty of Social Sciences: Založba FDV, p. 95-104.

16. SILVERSTONE, R. (1994). Television and Everyday Life. London and New York: Routledge.

17. SILVERSTONE, R. (2007). Media and morality: On the rise of the mediapolis. Cambridge, England: Polity Press.

18. SVITICH, L. G. and ZASOURSKIY, Ya. N. (Eds.) (1988). Rabochaya kniga redaktora raionnoi gazety: Opyt, metodiki, rekomendacii (Workbook of the editor of the local newspaper: Experience, techniques, recommendations). Moscow: Mysl' (in Russian).

19. TITOV, A. (2012). Ot kommercializacii k sociozhurnalistike? Scenarii razvitiya na primere russkoyazychnyh pechatnyh SMI Estonii (From commercialization to socio journalism? The development scenario on the example of Russian-speaking print media of Estonia). In: $O$. Savinova (Ed.), SMI i duhovnaya zhizn' obshestva (Mass media and spiritual life of society). Nizhny Novgorod: Lobachevsky State University of Nizhni Novgorod, p. 23-34 (in Russian).

20. TURNER, G. (2010). Ordinary people and the media: The demotic turn. London: SAGE Publications Ltd. doi: http://dx.doi.org/10.4135/9781446269565. 